\title{
ASOSIASI GASTROPODA DENGAN TUMBUHAN LAMUN DI PERAIRAN PANTAI NEGERI TIOUW KECAMATAN SAPARUA KABUPATEN MALUKU TENGAH
}

\author{
Anggi Wawan Batuwael ${ }^{1}$, D. Rumahlatu ${ }^{2}$ \\ ${ }^{1}$ Alumni Program Studi Pendidikan Biologi \\ 2Dosen Program Studi Pendidikan Biologi \\ E-mail: dominggus_amq@yahoo.co.id
}

\begin{abstract}
Background: Seagrasses are flowering plants (Angiosperms) that are able to adapt fully in waters with high salinity or live immersed in water. Seagrass has true rhizomes, leaves and roots like plants on land. Seagrasses usually form fields called seagrass beds, especially in tropical and sub-tropical regions. The existence of seagrasses is known to support fishing activities, shellfish communities and other invertebrate biota.

Method: This study is a descriptive study to reveal information about environmental characteristics, and associations of seagrasses with gastropods.

Results: The study found a class of gastropods, 10 species namely Strombus variabilis, Strombus microurceus, Nassariusl uridus, Nassarius dorsatus, Strombus urceus, Cypraea annulus, Strombus labiatus, Strombus marginatus, Neritas quamulata, Cypraeratigris. Of the seagrass plants found 4 species, namely Enhalus acoroides, Thalassia hemprichii, Halophila ovalis, Cymodocea rotundata. Association values ranged from 4.159-8.85 with positive and negative types. This means that both types of seagrass are often found together or not found together in each observation box.

Conclusion: There is a weak association between seagrass and gastropods in the coastal waters of Tiouw State. The association of gastropod types with seagrass species is found in 10 types of gastropods and 4 types of seagrasses in the waters of the Tiouw State coast.
\end{abstract}

Keywords: Seagrass, gastropods, associations

\begin{abstract}
Abstrak
Latar Belakang: Lamun merupakan tumbuhan berbunga (Angiospermae) yang mampu beradaptasi secara penuh di perairan yang salinitasnya cukup tinggi atau hidup terbenam di dalam air. Lamun memiliki rhizoma, daun, dan akar sejati seperti tumbuhan di darat. Lamun biasanya membentuk padang yang disebut ekosistem padang lamun (Seagrass Bed) terutama di daerah tropis dan sub tropis. Keberadaan lamun diketahui mendukung aktivitas perikanan, komunitas kerang-kerangan dan biota avertebrata lainnya.

Metode: Penelitian ini adalah penelitian deskriptif untuk mengungkapkan informasi tentang karakteristik lingkungan, dan asosiasi lamun dengan gastropoda.

Hasil: Penelitian menemukan kelas gastropoda, 10 spesies yaitu Strombus variabilis, Strombus microurceus, Nassarius luridus, Nassarius dorsatus, Strombus urceus, Cypraea annulus, Strombus labiatus, Strombus marginatus, Neritas quamulata, Cypraeratigris. Dari tumbuhann lamun ditemukan 4 spesies yaitu Enhalus acoroides, Thalassia hemprichii, Halophila ovalis, Cymodocea rotundata. Nilai asosiasi berkisar antara 4,159-8,85 dengan tipe positif dan negatif. Hal ini berarti kedua jenis lamun tersebut sering ditemukan bersama-sama atau tidak ditemukan bersama-sama dalam setiap kotak pengamatan.

Kesimpulan: Terdapat hubungan asosiasi yang lemah antara lamun dengan gastropoda di perairan pantai Negeri Tiouw. Asosiasi jenis gastropoda dengan jenis lamun yaitu, ditemukan 10 jenis gastropoda dan 4 jenis lamun di Perairan pantai Negeri Tiouw.
\end{abstract}

Kata Kunci: Lamun, gastropoda, asosiasi

Anggi Wawan Batuwael, D. Rumahlatu, Asosiasi Gastropoda Dengan ... 109 


\section{PENDAHULUAN}

Daerah pesisir dan laut memiliki tiga ekosistem penting bagi biota laut, salah satunya adalah ekosistem padang lamun. Pentingnya ekosistem padang lamun adalah sebagai produsen primer, pendaur unsur hara, penstabilan dasar perairan dengan sistem perakarannya yang dapat menangkap sedimen, sebagai habitat, tempat pemijahan, tempat pengasuhan dan sumber makanan serta tempat berlindung bagi biota laut (Fitri Marbun, 2017 dalam Nybakken, 1992).

Ekosistem padang lamun banyak dihuni oleh berbagai jenis biota laut, seperti kepiting, udang, moluska, teripang dan berbagai jenis ikan. Salah satu kelompok fauna yang banyak ditemukan berasosiasi dengan padang lamun adalah gastropoda, baik yang hidup sebagai epifauna (di atas permukaan) maupun infauna (di dalam substrat). Saripantung, 2013, menyatakan bahwa komunitas gastropoda merupakan komponen yang penting dalam rantai makanan di ekosistem padang lamun, karena gastropoda merupakan hewan dasar pemakan detritus (detritus feeder), serasah dari daun lamun dan mensirkulasi zat-zat yang tersuspensi di dalam air.

Lamun merupakan tumbuhan berbunga (Angiospermae) yang mampu beradaptasi secara penuh di perairan yang salinitasnya cukup tinggi atau hidup terbenam di dalam air. Lamun memiliki rhizoma, daun, dan akar sejati seperti halnya tumbuhan di darat (Nontji, 1987; Nasmia, 2012 dalam Gosari dan Haris, 2012). Lamun biasanya membentuk padang yang disebut ekosistem padang lamun (Seagrass Bed) terutama di daerah tropis dan subtropis. Komunitas lamun memegang peranan penting baik secara ekologis, maupun biologis di daerah pantai dan estuaria. Keberadaan lamun diketahui mendukung aktifitas perikanan, komunitas kerang - kerangan dan biota avertebrata lainnya (Bastyan dan Cambridge, 2008 dalam Gosari dan Haris, 2012).

Kelas gastropoda umumnya dikenal dengan keong atau siput. Gastropoda merupakan moluska yang paling kaya akan jenis. Cangkangnya berbentuk tabung melingkar - lingkar seperti spiral. Menurut Nontji (2007) mengatakan bahwa tabung cangkang gastropoda yang melingkar- lingkar itu memilin (coiled) ke kanan yakni searah putaran jarum jam bila dilihat dari ujungnya yang runcing. Namun adapula yang memilih ke kiri. Pertumbuhan cangkang yang memilin bagai spiral itu disebabkan karena pengendapan bahan cangkang disebelah luar berlangsung lebih cepat dari yang sebelah dalam. Secara ekologi, gastropoda merupakan komponen penting dalam rantai makanan di ekosistem padang lamun dan bermanfaat terhadap pertumbuhan padang lamun dalam proses fotosintesis (Fitri Marbun, 2017 dalam Kusnadi, 2009; Sianu, 2014). Selain penting secara ekologi, beberapa gastropoda juga memiliki nilai ekonomis yang tinggi karena cangkang gastropoda dimanfaatkan untuk kerajinan tangan sedangkan dagingnya dimanfaatkan untuk dikonsumsi.

Salah satu biota laut yang ada dalam rantai makanan tersebut yaitu filum moluska kelas Gastropoda. Filum moluska kelas Gastropoda memiliki peran ekologi yang penting di ekosistem padang lamun. Dimana biomassa epifit yang menempel pada daun lamun akan dimanfaatkan oleh moluska tree fauna sebagai sumber makanan dan protein, sehingga kehadiran moluska sangat berguna bagi lamun. Hubungan rantai makanan antara moluska dan lamun disebut dengan asosiasi. Tarumingkeng (1994) dalam Paillin (2009) menyatakan bahwa asosiasi merupakan ukuran kemampuan atau keeratan antara spesies. Salah satu moluska laut yang berasosiasi dengan padang lamun yaitu Gastropoda. Hewan moluska kelas Gastropoda merupakan salah satu kelompok invertebrata yang berasosiasi baik dengan padang lamun di Indonesia. Menurut Syari (2005) bahwa Gastropoda sangat bermanfaat terhadap pertumbuhan padang lamun dalam melakukan proses fotosintesis, Gastropoda (keong) adalah salah satu kelas dari Moluska yang diketahui berasosiasi dengan baik terhadap ekosistem lamun. Komunitas Gastropoda merupakan komponen yang penting dalam rantai makanan di padang lamun, dimana Gastropoda merupakan hewan dasar pemakan detritus (detritusfeeder) dan serasah dari daun lamun yang jatuh dan mensirkulasi zat-zat yang tersuspensi di dalam air guna mendapatkan makanan. 
Negeri Tiouw yang berada di Kecamatan Saparua Kabupaten Maluku tengah yang menjadi salah satu daerah penyebaran lamun. Berdasarkan hasil observasi dan wawancara dengan masyarakat setempat telah mengetahui keberadaan dan fungsi lamun sebagai tempat biota laut menempelkan telurnya. Mengingat pentingnya manfaat Gastropoda dan asosiasinya dengan lamun bagi lingkungan dan sumberdaya hayati perairan dalam menunjang ekosistem pesisir secara umum, maka dari itu diperlukan adanya kajian penelitian tentang komponenkomponen dan interaksi antara komponen penyusun ekosistem tersebut.

\section{MATERIAL DAN METODE}

Tipe penelitian yang digunakan dalam penelitian ini adalah penelitian deskriptif untuk mengungkapkan informasi tentang karakteristik lingkungan, dan asosiasi lamun dengan gastropoda. Pengambilan sampel secara insitu di perairan pantai negeri tiouw. Identifikasi spesies di perpustakaan LIPI Ambon. Penelitian ini berlangsung selama 1 minggu, dimulai pada tanggal 24 januari 31 januari 2018.

Populasi dalam penelitian ini adalah seluruh jenis lamun dan jenis gastropoda yang terdapat di peraiaran pantai Negeri Tiouw. Sampel dalam penelitian ini adalah jenis-jenis lamun dan gastropoda yang terdapat dalam petak/plot.

Tahap persiapan yang perlu dilakukan oleh peneliti sebelum melaksanakan penelitian adalah melakukan studi pendahuluan (observasi) pada lokasi yang akan diteliti. Hal ini bertujuan untuk mengetahui dan memastikan lokasi yang akan di gunakan untuk penenlitian, sekaligus menyiapkan alat dan bahan yang diperlukan pada saat penelitian.

Prosedur yang digunakan dalam penelitian ini, yaitu :

1. Mengukur panjang garis pantai

2. Menetukan garis transek dengan menggunakan rol meter dan pemetaan kuadrat, dimana tali transek di tarik tegak lurus dari garis pantai $50 \mathrm{~m}$ dengan jarak antar transek $10 \mathrm{~m}$ dan antar plot/petak pengamatan $10 \mathrm{~m}$.

3. Pada setiap transek di buat plot dengan ukuran $1 \times 1 \mathrm{~m}$.

4. Mengukur suhu, salinitas dan $\mathrm{pH}$ kemudian mencatat hasilnya pada table hasil pengamatan.

5. Melakukan pengamatan dan perhitungan terhadap jenis lamun dan gastropoda yang di temukan pada setiap plot dan mencatat hasilnya pada table hasil pengamatan kemudian di identifikasi.

\section{Pengambilan Sampel}

1. Pengambilan sampel lamun dilakukan dengan menggunakan metode transek linier (Krebs, 1999).

2. Sebelumnya dilakukan survey awal dengan mengukur luas area penelitian.

3. Kemudian tali transek di tarik tegak lurus dari garis pantai sepanjang $50 \mathrm{~m}$ dengan jarak transek $10 \mathrm{~m}$.

4. Pada setiap transek di letakan 5 plot yang berukuran $1 \times 1 \mathrm{~m}$ dengan jarak antar plot $10 \mathrm{~m}$.

5. Pada setiap plot dicatat tiap spesies lamun yang di temukan pada setiap unit pengamatan dan di ambil sala satu tegakan sebagai contoh dimasukan ke dalam kantong plastic sampel yang di beri label untuk keperluan identifikasi.

6. Gastropoda yang di temukan di dalam plot yang menempel pada lamun dan di atas substrat perairan diambil, di cuci bersih, dan dimasukan ke dalam kantung plastic sampel yang diberi label dan di awetkan dalam larutan alkohol untuk keperluan identifikasi.

Pengukuran parameter fisika dan kimia yang diukur dalam penelitian ini adalah parameter yang sangat berpengaruh terhadap perubahan penyebaran gastropoda yaitu $\mathrm{pH}$, suhu, dan salinitas. Parameter fisika dan kimia perairan yang diukur beserta alat/metode yang digunakan dapat dilihat pada Tabel 3 . 
Tabel 3. Metode Pengukuran Parameter Fisika dan Kimia

\begin{tabular}{|c|c|c|c|c|}
\hline & Parameter & Satuan & Metode & Keterangan \\
\hline $\begin{array}{l}\text { Fisika: } \\
\text { Suhu }\end{array}$ & & ${ }^{\circ} \mathrm{C}$ & Thermometer/Pemuaian & Insitu \\
\hline $\begin{array}{c}\text { Kimia: } \\
\text { pH } \\
\text { Salinitas }\end{array}$ & & $\overline{\%}$ & $\begin{array}{c}\text { Kertas Lakmus } \\
\text { Hand Refractometer }\end{array}$ & $\begin{array}{l}\text { Insitu } \\
\text { Insitu }\end{array}$ \\
\hline
\end{tabular}

Kerapatan lamun, dapat dihitung dengan rumus menurut (Sabandar, D. A, 2017 dalam Tuwo, 2011).

$\mathrm{D}=\frac{\text { Jumlah Tegakan }}{\text { Luas Daerah petak Pengamatan }}$

Skala kondisi padang lamun berdasarkan kerapatannya dapat dilihat pada Tabel 4 .

Tabel 4. Skala Kondisi Padang Lamun Berdasarkan Kerapatan

\begin{tabular}{ccc}
\hline Skala & Kerapatan $\left(\right.$ ind $\left./ \mathbf{m}^{2}\right)$ & Kondisi \\
\hline $\mathbf{5}$ & $>175$ & Sangat rapat \\
$\mathbf{4}$ & $125-175$ & Rapat \\
$\mathbf{3}$ & $75-125$ & Agak rapat \\
$\mathbf{2}$ & $25-75$ & Jarang \\
$\mathbf{1}$ & $<25$ & Sangat jarang \\
\hline
\end{tabular}

Data yang di peroleh dianalisis secara deskriptif, dengan sumber data sebagai berikut : Asosiasi antar spesies gastropoda dengan spesies lamun di analisa dengan menggunakan tabel kontigensi $2 \times 2$, kemudian di hitung dengan uji chi-square $\left(x^{2}\right)$ (Ludwig dan reynold, dalam Soumokil 2005) sebagai berikut.

\section{Tabel 5. Tabel Kontigensi 2x2}

\begin{tabular}{|c|c|c|c|}
\hline \multirow[b]{2}{*}{ Spesies A } & \multicolumn{2}{|c|}{ Spesies B } & \multirow[b]{2}{*}{ total } \\
\hline & Ada & Tidak ada & \\
\hline Ada & $a$ & $b$ & $a+b$ \\
\hline Tidak ada & $c$ & $d$ & $c+d$ \\
\hline Total & $a+c$ & $b+d$ & $a+b+c+d=n$ \\
\hline
\end{tabular}

Dimana :

$a=$ jumlah plot yang terdapat spesies $A$ dan $B$ bersama-sama

$\mathrm{b}=$ jumlah plot yang terdapat spesies $A$ tetapi spesies $B$ tidak

$\mathrm{C}=$ jumlah plot yang terdapat spesies $\mathrm{B}$ tetapi spesies $\mathrm{A}$ tidak

$\mathrm{d}=$ jumlah plot yang tidak terdapat baik spesies $A$ juga spesies $B$

$\mathrm{n}=$ jumlah total plot (petak pengamatan)

Untuk mengetahui tipe asosiasi yang di peroleh apakah positif, negatif, atau tidak ada asosiasi dilakukan pengujian dengan chi-square $\left(x^{2}\right)$ dengan formula: 
Dengan:

$$
x^{2}=\frac{[a-E(a)]^{2}}{E(a)}+\frac{[b-E(b)]^{2}}{E(b)}+\frac{[c-E(c)]^{2}}{E(c)}+\frac{[d-E(d)]^{2}}{E(d)}
$$

$$
\begin{gathered}
E(a)=\frac{(a+b) x(a+c)}{\mathrm{n}} \\
E(b)=\frac{(a+b) x(b+d)}{\mathrm{n}} \quad E(c)=\frac{(a+c) x(c+d)}{\mathrm{n}} \\
E(d)=\frac{(b+d) x(c+d)}{\mathrm{n}}
\end{gathered}
$$

Dimana:

$\mathrm{a}, \mathrm{b}, \mathrm{c}, \mathrm{d}=$ jumlah pengamatan yang diperoleh.

$\mathrm{E}=$ jumlah petak pengamatan yang diperoleh

Tipe asosiasi ditentukan Berdasarkan indicator dengan nilai (Ludwig and Reynold dalam Soumokil, 2005) Jika nilai a>E (a), maka tipe asosiasi positif dan Jika nilai $a<E$ (a), maka tipe asosiasi negatif). Nilai $x^{2}$ tabel dengan tingkatan nilai adalah 3,84 baik asosiasi positif maupun negatif, dan dinyatakan tidak terdapat hubungan yang signifikan $(\alpha=0,05)$ (Widiyanto, 2013).

Analisis Asosiasi Berdasarkan Ukuran Kekuatan

Untuk mengetahui tingkat asosiasi antara gasropoda dengan tumbuhan lamun digunakan Indeks Ochiai (Ludwig and Reynolds, 1988).

Indeks Ochiai (OI)

$\mathbf{O} \mathbf{I}=\frac{a}{\sqrt{a+b} \sqrt{a+b}}$

\section{Dimana :}

$\mathrm{a}=$ jumlah plot ditemukannya kedua jenis (A dan $B$ )

$\mathrm{b}=$ jumlah plot ditemukannya jenis $\mathrm{A}$ tetapi tidak jenis $B$

$\mathrm{C}=$ jumlah plot ditemukannya jenis $\mathrm{B}$ tetapi tidak jenis $A$

Asosiasi terjadi pada selang nilai $0-1$, semakin mendekati angka 1 maka semakin kuat hubungan kedua jenis tersebut, demikian pula sebaliknya.

\section{HASIL DAN PEMBAHASAN}

Penelitian ini di laksanakan di perairan pantai negeri Tiouw. Berdasarkan pengukuran parameter lingkungan pada kedua transek pengamatan ditemukan kisaran rata-rata nilai suhu perairan $36^{\circ} \mathrm{C}$, Nilai rata-rata salinitas pada lokasi penelitian baik transek I dan transek II ditemukan kisaran rata-rata nilai salinitas $31 \%$, Nilai derajat keasaman $(\mathrm{pH})$ di lokasi pengamatan kisaran rata-rata yaitu 7 . Berikut adalah gambaran kondisi faktor lingkungan fisika-kimia di perairan pantai Negeri Tiouw.

\section{Gambar 1. Grafik Pengukuran Suhu, Salinitas dan pH di Perairan Pantai Negeri Tiouw.}

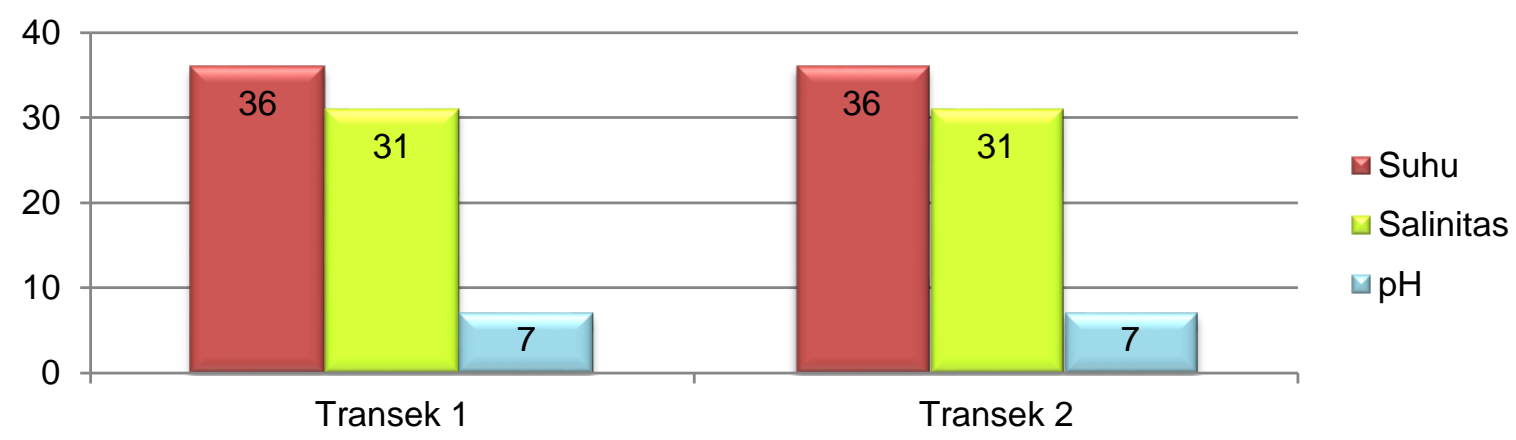


Tipe substrat pada ekosistem lamun di perairan pantai negeri tiouw sebagian besar terdiri dari pasir berlumpur, patahan karang mati. Berdasarkan tabel 6 dilihat bahwa terdapat 4 jenis lamun ditemukan pada perairan pantai Negeri Tiouw. Spesies- spesies lamun tersebut terdiri dari 1 kelas (Magnoliopsida) $1 \quad$ subkelas (Monocotyledonae), 2 famili (Hidrocharitaceaae, Potamogetonaceae) dan 4 spesies $(H$. ovalis, E. acoroides, $T$. emprichii, $C$. rotundata) sebagai berikut.

Tabel 6. Jenis Lamun yang ditemukan di Perairan Pantai Negeri Tiouw

\begin{tabular}{ccccl}
\hline Kelas & Sub Kelas & Famili & Genus & Spesies \\
\hline \multirow{2}{*}{ Angiospermae } & \multirow{2}{*}{ Monocotyledonae } & Hidrocharitaceaae & Halophila & H. ovalis \\
& & Enhalus & E. acoroides \\
& & & Thalasia & T. emprichii \\
& & Potamogetonaceae & Cymodocea & C. rotundata \\
\hline
\end{tabular}

Gastropoda yang ditemukan pada lokasi penelitian berjumlah 10 spesies yaitu Strombus variabilis, Strombus microurceus, Nassarius luridus, Nassarius dorsatus, Strombus urceus, Cypraea annulus,
Strombus labiatus, Strombus marginatus, Nerita squamulata, Cypraera tigris. Berdasarkan tabel 7 dilihat bahwa terdapat 10 jenis gastropoda yang ditemukan.

Tabel 7. Jenis Makroepifauna yang ditemukan di Perairan Pantai Negeri Tiouw

\begin{tabular}{|c|c|c|c|c|}
\hline Kelas & Ordo & Famili & Genus & Spesies \\
\hline \multirow{8}{*}{ Gastropoda } & Archaeogastropoda & Neritidae & Nerita & Nerita squamulata \\
\hline & & Cypraeidae & Cypraea & $\begin{array}{l}\text { Cypraea annulus } \\
\text { Cypraea tigris }\end{array}$ \\
\hline & Mesogastropoda & & & Strombus urceus \\
\hline & & Strombidae & Strombus & Strombus variabilis \\
\hline & & & & $\begin{array}{l}\text { Strombus } \\
\text { microurceus }\end{array}$ \\
\hline & & & & Strombus marginatus \\
\hline & & & & Strombus labiatus \\
\hline & Neogastropoda & Nassaridae & Nassarius & $\begin{array}{l}\text { Nassarius luridus } \\
\text { Nassarius dorsatus }\end{array}$ \\
\hline
\end{tabular}

Berdasarkan Grafik 2 di bawah ini terlihat bahwa kerapatan lamun paling dominan pada transek I (plot I) sebanyak $532 \mathrm{teg} / \mathrm{m}^{2}$, pada transek II (plot I) sebanyak $472 \mathrm{teg} / \mathrm{m}^{2}$. Nilai kerapatan ini mengindikasikan bahwa tiap kerapatan berbeda-beda tergantung dari tipe substrat pada tiap stasiun dan juga dipengaruhi oleh faktor lingkungan dan aktivitas yang dilakukan masyarakat disekitar lamun tersebut. 
Gambar 2. Grafik Kerapatan Lamun di Perairan Pantai Negeri Tiouw

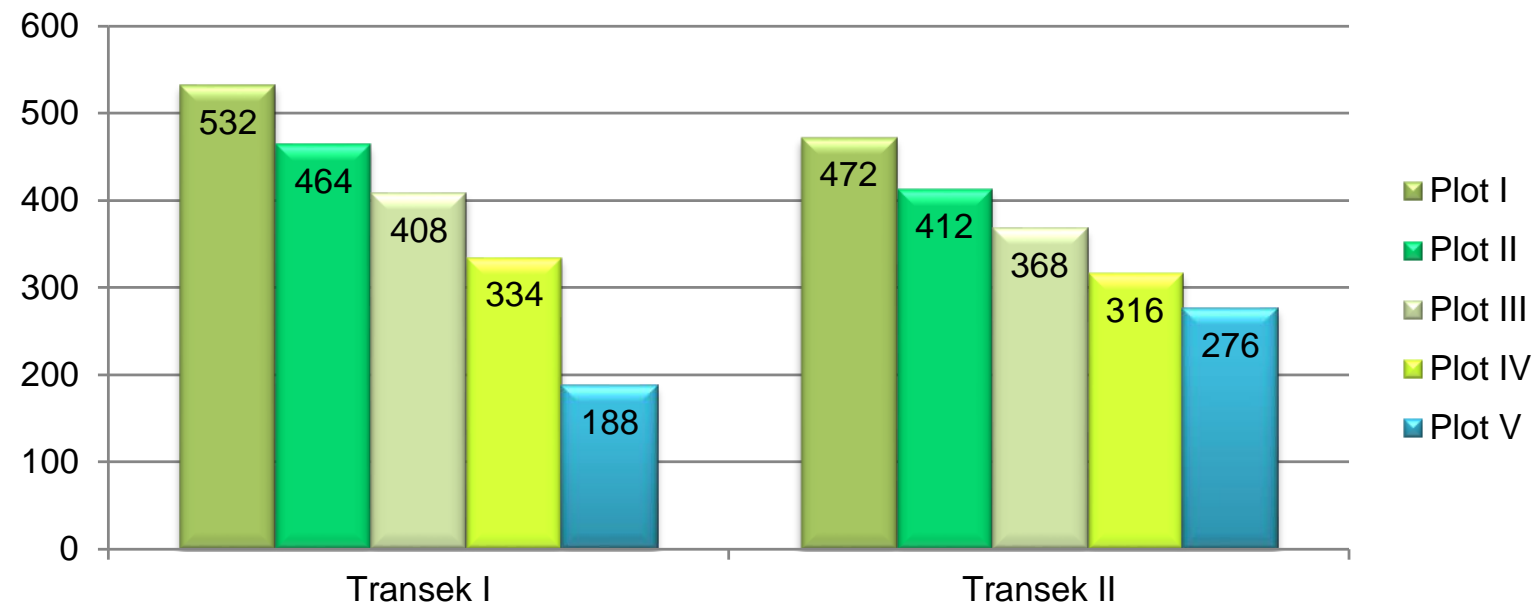

Berdasarkan hasil analisis diperoleh sebanyak 4 jenis gastropoda yang berasosiasi dengan 3 jenis lamun, meliputi: 1) Strombus variabilis dan Thalassia hemprichii dengan nilai asosiasi sebesar 5,833 dan memiliki tipe asosiasi positif. 2) Strombus marginatus dan Thalassia hemprichii, Cymodocea rotundata dengan nilai asosiasi sebesar 8,85 dan memiliki tipe asosiasi negatif. 3) Nerita squamulata dan Thalassia hemprichii dengan nilai asosiasi sebesar 5,833 dan memiliki tipe asosiasi negatif. 4) Cypraera tigris dan Halophila ovalis dengan nilai asosiasi sebesar 4,159 dan memiliki tipe asosiasi positif.

Asosiasi jenis lamun dengan gastropoda di perairan pantai Negeri Tiouw, dapat dilihat pada tabel 8 .

Tabel 8. Asosiasi Jenis Lamun dan Gastropoda di Perairan Pantai Negeri Tiouw

\begin{tabular}{lcccc}
\hline \multirow{2}{*}{ Gastropoda } & \multicolumn{5}{c}{ Lamun } \\
\cline { 2 - 5 } & E. acoroides & T. hemprichii & H. ovalis & C. rotundata \\
\hline Strombus variabilis & 2,857 & 5,833 & 0,022 & 2,571 \\
Strombus & 0 & 0 & 0 & 0 \\
microurceus & & 0 & 0 & 0 \\
Nassarius luridus & 0 & 0 & 0 & 0 \\
Nassarius dorsatus & 0 & 2,5 & 0,476 & 2,5 \\
Strombus urceus & 1,666 & 0 & 0,476 & 2,5 \\
Cypraea annulus & 1,666 & 0,476 & 2,857 & 1,071 \\
Strombus labiatus & 1,269 & 8,85 & 0,609 & 8,85 \\
Strombus & 0,625 & & & \\
marginatus & & 5,833 & 1,836 & 1,071 \\
Nerita squamulata & 2,857 & 0,356 & 4,159 & 0,356 \\
Cypraera tigris & 0,740 & & & \\
\hline
\end{tabular}

Berdasarkan tabel 9 dapat dilihat bahwa ternyata nilai indeks asosiasi beberapa jenis gastropoda dan beberapa jenis tumbuhan lamun yang kehadirannya di perairan pantai negeri tiouw memiliki hubungan kekuatan asosiasi yang tergolong minimum. indeks asosiasi Strombus variabilis dan Thalassia hemprichii yang berasosiasi paling kuat dengan Indeks Ochiai 1,322. Dan diikuti oleh pasangan yang nilai indeksnya sama (1) Strombus marginatus dan Thalassia hemprichii 0,5; (2) Strombus marginatus dan cymodocea rotundata 0,$5 ;$ (3) Cypraera tigris dan Halophila ovalis 0,5 . 
Tabel 9. Tingkat Asosiasi Jenis Lamun dan Gastropoda di Perairan Pantai Negeri Tiouw

\begin{tabular}{clc}
\hline No & \multicolumn{1}{c}{ Pasangan spesies } & Ol \\
\hline 1 & Strombus variabilis - Thalassia hemprichii & 1,322 \\
2 & Strombus marginatus - Thalassia hemprichii & 0,5 \\
3 & Strombus marginatus - cymodocea rotundata & 0,5 \\
4 & Cypraera tigris - Halophila ovalis & 0.5 \\
\hline
\end{tabular}

Keterangan: Ol: Indeks Ochiai

\section{KESIMPULAN}

Kondisi Lingkungan Fisika-Kimia hasil pengukuran suhu dengan kisaran rata-rata pada saat pengambilan sampel baik transek I maupun transek II yaitu $36{ }^{\circ} \mathrm{C}$. Salinitas dengan kisaran rata-rata sama baik transek I maupun transek II yaitu 31(\%o). pH dengan kisaran rata-rata sama yaitu 7 (netral). Adanya hubungan asosiasi yang lemah antara lamun dengan gastropoda di perairan pantai Negeri Tiouw. Asosiasi jenis gastropoda dengan jenis lamun yaitu, ditemukan 10 jenis gastropoda dan 4 jenis lamun di Perairan pantai Negeri Tiouw.

\section{DAFTAR PUSTAKA}

Gosari, B. A. J., dan Haris. A. 2012. Studi Kerapatan Dan Penutupan Jenis Lamun Di Kepulauan Spermonde. Jurnal IImu Kelautan dan Perikanan Universitas Hasanuddin Makassar. 22(3): 156-162.

Krebs, J. Charles. 1999. Ecological Methology Second Edition. Menlo Park: Benjamin Cummings.

Kusnadi, A. 2009. Molluska Padang Lamun Kepulauan Kei Kecil. Penerbit LIPI Press. Jakarta. 187 Hal.

Ludwig dan Reynold. 1988. Statistical Ecology. John Wiley and Sons; New York.

Nontji, A. 2007. Laut Nusantara (Edisi revisi). Penerbit Djambatan. Jakarta.

Nybaken, J.W. 1992. Bilogi Laut: Suatau Pendekatan Ekologis. PT. Gramedia; Jakarta.

Paillin, J.B. (2009). Asosiasi Inter-Spesies Lamun di Perairan Ketapang Kabupaten Seram Bagian Barat. Jurnal TRITON. 5 (2): 19-25

Saripantung, G. L., J. F. W. S. Tamanampo dan G. Manu. 2013. Struktur Komunitas Gastropoda di Hamparan Lamun
Daerah Intertidal Kelurahan Tongkeina Kota Manado. Jurnal IImiah Platax. ISSN: 2302-3589. 1 (3): 103.

Sianu, Novi Efrianti, 2014. Keanekaragaman dan Asosiasi Gastropoda dengan Ekosistem Lamun di Perairan Teluk Tomini Sekitar Desa Tabulo Selatan Kecamatan Mananggu Provinsi Gorontalo. Jurnal Ilmiah Perikanan dan Kelautan, 2(4): 156 163.

Soumokil, A.W., 2005. Pengaruh Kecepatan Debit Air Terhadap Kehadiran Parasit Pada Ikan Mas Cyprinus carpio. Prosiding Konferensi Akuakultur Indonesia.

Susetiono. (2007). Lamun dan Fauna Teluk Kuta, Pulau Lombok. Jakarta: LIPI Press.

Syari, A. I. 2005. Asosiasi Gastropoda di Ekosistem Padang Lamun Perairan Pulau Lepar Provinsi Kepulauan Bangka Belitung. Skripsi. Fakultas Perikanan Dan Ilmu Kelautan. Institut Pertanian Bogor.

Tuwo, A. (2011). Pengelolaan Ekowisata Pesisir dan Laut - Pendekatan Ekologi, Sosial Ekonomi, Kelembagaan dan Sarana Wilayah (Pertama). Surabaya: Brilian Internasional.

Widiyanto, J. 2013. Keanekaragaman Gastropoda Air Tawar di Berbagai Macam Habitat di Kecamatan Tanambulava Kabupaten Sigi. Jurnal FKIP Progam Studi Pendidikan Biologi, Universitas Tadulako. E-Jip biol Vol. 2: 13-19. 